\title{
Combined effects of exogenous enzymes and probiotic on Nile tilapia (Oreochromis niloticus) growth, intestinal morphology and microbiome
}

by Adeoye, A.A., Yomla, R., Jaramillo-Torres, Rodiles, A., Merrifield, D.L. and Davies, S.J.

Copyright, Publisher and Additional Information: This is the authors' accepted manuscript. The final published version (version of record) is available online via Elsevier Please refer to any applicable terms of use of the publisher. 


\title{
Combined effects of exogenous enzymes and probiotic on Nile tilapia (Oreochromis niloticus) growth, intestinal morphology and microbiome
}

\author{
Ayodeji A. Adeoye ${ }^{\text {ac* }}$, Rungtawan Yomla ${ }^{\text {ad }}$, Alexander Jaramillo-Torres ${ }^{\mathrm{a}}$, Ana Rodiles ${ }^{\mathrm{a}}$, \\ Daniel L. Merrifield ${ }^{a}$ and Simon J. Davies ${ }^{b}$ \\ ${ }^{a}$ School of Biological Sciences, Plymouth University, UK \\ ${ }^{\mathrm{b}}$ Department of Animal Production, Welfare and Veterinary Sciences, Harper Adams \\ University, UK \\ ${ }^{c}$ Department of Aquaculture and Fisheries Management, Federal University of Agriculture, \\ Abeokuta - Nigeria \\ ${ }^{\mathrm{d}}$ Faculty of Agricultural Technology, King Mongkut's Institute of Technology Ladkrabang, \\ Thailand
}

\section{Abstract}

A study was carried out to investigate the combined effect of exogenous enzymes and probiotic supplementation on tilapia growth, intestinal morphology and microbiome composition. Tilapia (34.56 $\pm 0.05 \mathrm{~g})$ were fed one of four diets (35\% protein, $5 \%$ lipid); one of which was a control and the remaining three diets were supplemented with either enzymes (containing phytase, protease and xylanase), probiotic (containing Bacillus subtilis, B. licheniformis and B. pumilus) or enz-pro (the combination of the enzymes and probiotic). Tilapia fed diet supplemented with enz-pro performed better $(P<0.05)$ than tilapia fed the control and probiotic supplemented diets in terms of final body weight (FBW), specific growth rate (SGR), feed conversion ratio (FCR) and protein efficiency ratio (PER). The dietary treatments did not affect somatic indices. The serum lysozyme activity was significantly higher $(P<0.05)$ in tilapia fed the probiotic supplemented diet than of those fed the remaining experimental diets. The intestinal perimeter ratio was higher $(P<0.05)$ in tilapia fed enz-pro supplemented diet when compared to those fed with the control and probiotic supplemented diets. Goblet cells abundance, microvilli diameter and total

\footnotetext{
Corresponding author: Ayodeji Adeoye, School of Biological Sciences, Plymouth University, Plymouth - UK, PL4 8AA. E-mail address: ayodeji.adeoye@plymouth.ac.uk. Tel: +44 1752584684
} 
30 enterocyte absorptive surface was higher $(P<0.05)$ in tilapia fed diet supplemented with 31 enz-pro than those fed the control diet. High-throughput sequencing revealed that majority of

32 reads derived from the tilapia digesta belonged to members of Fusobacteria (predominantly 33 Cetobacterium) distantly followed by Proteobacteria and Firmicutes. The alpha and beta 34 diversities did not differ among dietary treatments indicating that the overall microbial 35 community was not modified to a large extent by dietary treatment. In conclusion, 36 supplementation of the diet with a combination of enzymes and probiotic is capable of 37 improving tilapia growth and intestinal morphology without deleterious effect on the 38 intestinal microbial composition.

40 Keywords: Enzymes, probiotic, histology, microbiome, high-throughput sequencing, tilapia 


\subsection{Introduction}

42 The growth of aquaculture, the world's fastest growing food production sector, is linked to 43 population increase and consequently the intensification and diversification of aquaculture 44 operations (Msangi et al., 2013). The rearing technologies for the intensive operations in aquaculture under poor management can be accompanied by sub-optimum environmental conditions as a result of overcrowding and overfeeding. These conditions may be stressful for fish, leading to decreased performance and subsequently compromised immune responses which leave fish prone to infection and disease by opportunistic pathogens. However, with the need to meet global animal protein demand and the growing pressure on fish farmers to reduce production cost without necessarily transferring the cost to the consumers, the stressful conditions associated with the intensive aquaculture operation is likely to continue in many parts of the world. The growing concept of immune-nutrition (production of high quality feed with optimal growth and immune boosting effects) could be of benefit to

54 intensive aquaculture operations (Nakagawa et al., 2007, Kiron, 2012).

The gastro-intestinal (GI) microbiota of fish has been reported to play a key role in nutrition and immunity. According to Nayak (2010), GI microbiota are involved in major nutritional functions which include digestion, nutrient utilisation and the production of specific amino acids, enzymes, short-chain fatty acids, vitamins and mineral availability. The nutritional role of GI microbiota includes the production of vitamins and the secretion of digestive enzymes that promote nutrient digestion as well as synthesise nutrients and metabolites required by fish (Okutani et al., 1967, Saha et al., 2006, Li et al., 2010, Liu et al., 2016). In addition, GI microbiota are capable of influencing immune status, disease resistance, survival, feed utilisation and may have a role in preventing pathogens from colonising the host (Denev et al.,

64 2009, Ring $\varnothing$ et al., 2015). Apart from nutrition and immunological effects, fish GI microbiota 
have important functions in host metabolism, mucosal development and promote gut maturation (Bates et al., 2006, Rawls et al., 2004, Round and Mazmanian, 2009).

It is well established that GI microbial communities are sensitive to rearing environment,

68 seasonal and diet changes including the supplementation with probiotic (Dimitroglou et al., 2011, Merrifield et al., 2010, Romero et al., 2014) and exogenous digestive enzymes (Bedford and Cowieson, 2012, Geraylou et al., 2012, Zhou et al., 2013, Jiang et al., 2014, Adeoye et al., 2016, Hu et al., 2016). Research into the use of exogenous digestive enzyme and probiotic supplements is increasing since aquafeed manufacturers are increasingly interested in producing 'functional and environmentally friendly aquafeeds'. The potential effects of exogenous digestive enzymes (Kumar et al., 2012, Castillo and Gatlin, 2015, Lemos and Tacon, 2016) and probiotic (Pérez - Sánchez et al., 2014) on fish have been reviewed as individual supplement. To the authors' understanding, there is no previous report on combined used of exogenous digestive enzymes and probiotic as supplement in fish. However, the combined supplementation of exogenous enzymes and probiotic could result in a complimentary mode of actions: ability to produce fibre-degrading enzymes by probiotic may complement endogenous enzyme activity. On the other hand, exogenous digestive enzymes may increase availability of suitable substrate for probiotic as well as promote the growth of other beneficial bacteria (GI microbiota).

Given the potential complimentary mode of actions of exogenous digestive enzymes and probiotic, the two products could improve the growth performance and health status of farmed fish when fed diets supplemented with both the enzymes and probiotic as a cocktail; Nile tilapia (Nile tilapia) is an important freshwater fish species of considerable economic value globally. Therefore, the objective of this study was to evaluate the combined effects of exogenous digestive enzymes and probiotic on growth, intestinal morphology and microbiome composition of Nile tilapia. 


\subsection{Materials and methods}

91

92

93

94

\subsection{Experimental design and diets preparation}

All experimental work involving fish was in accordance with the principles of the Animals (Scientific Procedures) Act 1986 and the Plymouth University Ethical Committee.

The trial was conducted in a flow - through aquaculture system in King Mongkut's Institute of Technology Ladkrabang - Thailand. The flow - through system contains 12 square concrete tanks (508 L capacity each) and were supplied with freshwater sourced from a local river system. Three hundred and sixty all male Nile tilapia (Oreochromis niloticus) of mean weight $34.56 \pm 0.05 \mathrm{~g}$ obtained from Charoen Pokphand farm in Thailand were randomly distributed (30 fish per tank) into the 12 tanks after two weeks of acclimatization. The photoperiod and water temperature $\left(30.34 \pm 0.15^{\circ} \mathrm{C}\right)$ was maintained at ambient condition. The water $\mathrm{pH}(6.20 \pm 0.22)$ and dissolved oxygen levels $\left(>5.0 \mathrm{mg} \mathrm{L}^{-1}\right)$ were monitored daily using a HQ40d pH meter and dissolved oxygen multi-parameter meter (HACH Company, Loveland, USA). $\mathrm{NH}_{3}\left(0.304 \pm 0.08 \mathrm{mg} \mathrm{L}^{-1}\right), \mathrm{NO}_{2}\left(0.016 \pm 0.002 \mathrm{mg} \mathrm{L}^{-1}\right)$ and $\mathrm{NO}_{3}(1.46 \pm 0.19$ $\mathrm{mg} \mathrm{L}^{-1}$ ) were also monitored on a weekly basis using a nutrient analyser (SEAL AQ2 Analyser, Hampshire, UK). A constant water flow of $4.9 \mathrm{~L} \mathrm{~min}^{-1}$ (per tank) was used during the experiment to maintain the water quality and ensure optimum conditions for the fish.

A commercial diet (No. 461; 35\% protein, 5\% lipid) was obtained from INTEQC Feed Co. Ltd., Thailand and was used as basal formulation. The commercial diet was ground in a blender to powder and sieved to remove large particles. An enzyme cocktail (containing phytase, protease and xylanase), Sanolife PRO-F (a mixture of Bacillus subtilis, B. licheniformis and B. pumilus) and a combination of the enzyme cocktail and Sanolife PRO-F were added to the diets separately as stated in Table 1 . The diets were coded as control (zero supplementation), enzymes (phytase, protease and xylanase supplementation), probiotic 
114 (probiotic supplementation) and enz-pro (enzymes and probiotic supplementation as a 115 cocktail). The diets were mixed thoroughly for $15 \mathrm{~min}$ to ensure homogeneity. Warm water 116 was added to form a consistency suitable for subsequent cold press extrusion. Afterwards, the 117 diets were dried in an air convection oven set at $45{ }^{\circ} \mathrm{C}$ for $24 \mathrm{~h}$. The basal diet served as the 118 control and was prepared in the same way as those supplemented with the enzymes cocktail 119 and probiotic, with the exception of the supplementation. Tilapia were fed the experimental 120 diets for seven weeks at $3 \%$ biomass day $^{-1}$ in three equal rations. Daily feed was adjusted on 121 a weekly basis by batch weighing following a $24 \mathrm{~h}$ deprivation period.

\subsection{Growth performance, feed utilisation and somatic indices}

123 Growth performance, feed utilisation and somatic indices were assessed by final body weight

124 (FBW), specific growth rate (SGR), feed conversion ratio (FCR), protein efficiency ratio 125 (PER), hepatosomatic index (HSI), viscero-somatic index (VSI) and condition factor (K), 126 Calculations were carried out using the following formulae:

127 SGR $=100((\ln \mathrm{FBW}-\ln \mathrm{IBW}) / \mathrm{T})$, where FBW = final body weight $(\mathrm{g})$ and IBW = initial 128 body weight $(\mathrm{g})$

$129 \quad \mathrm{FCR}=\mathrm{FI} / \mathrm{WG}$, where FI $=$ feed intake $(\mathrm{g})$ and $\mathrm{WG}=$ wet weight gain $(\mathrm{g})$

$130 \mathrm{PER}=\mathrm{WG} / \mathrm{PI}$, where $\mathrm{WG}=$ wet weight gain $(\mathrm{g})$ and $\mathrm{PI}=$ protein ingested $(\mathrm{g})$,

$\mathrm{K}=(100 \times \mathrm{FW}) / \mathrm{FL}^{3}$, where $\mathrm{FL}=\mathrm{FL}=$ final length $(\mathrm{cm})$

$132 \mathrm{HSI}=100(\mathrm{LW} / \mathrm{FBW})$, where $\mathrm{LW}=$ liver weight $(\mathrm{g})$ and FBW = final body weight $(\mathrm{g})$

$133 \mathrm{VSI}=100(\mathrm{VW} / \mathrm{FBW})$, where VW = visceral weight $(\mathrm{g})$

134 All fish were euthanized with buffered tricaine methanesulfonate, MS222 (Pharmaq Ltd. 135 Hampshire, UK) at a concentration of $200 \mathrm{mg} \mathrm{L}^{-1}$ followed by destruction of the brain prior to sampling. For proximate composition analysis (AOAC, 1995), at the onset of the trial 12 
fish were pooled to constitute three samples; at the end of the trial, three fish per tank were sampled. The fish were also used to record viscera weight and whole body weight in order to 139 calculate the HSI and VSI.

\subsection{Haemato - immunological parameters}

141 At the end of the feeding trial, blood from three fish per tank $(n=9)$ was taken from the 142 caudal arch using a 25 gauge needle and a $1 \mathrm{~mL}$ syringe after fish were anaesthetized with 143 MS222 (Pharmaq Ltd. Hampshire, UK) at $150 \mathrm{mg} \mathrm{L}^{-1}$. Blood smears were prepared for 144 determination of differential leucocyte counts and additional blood was left to clot for a 145 period of $12 \mathrm{~h}\left(\right.$ at $\left.4^{\circ} \mathrm{C}\right)$ to isolate serum. Serum was isolated by centrifugation at $3600 \mathrm{~g}$ for 5 146 min and was stored at $-80{ }^{\circ} \mathrm{C}$ until further analysis. Haematocrit (measured and read as $\%$ 147 packed cell volume; PCV), haemoglobin, red blood cells (RBC), serum lysozyme activity, 148 white blood cells (WBC) and differential leucocyte proportions were determined according to 149 standard methods as described by Rawling et al. (2009).

\section{$2.4 \quad$ Intestinal histology}

151 At the end of the trial, three fish per tank were sampled for histological appraisal (light, 152 scanning electron and transmission electron microscopy) of the mid-intestine $(n=9)$. For 153 light microscopy examination, the samples were fixed in $10 \%$ formalin, dehydrated in graded ethanol concentrations and embedded in paraffin wax. In each specimen, multiple sets of sections (5 mm thick) were stained with May-Grünwald Giemsa (MGG), haematoxylin and eosin (H\&E) and Alcian-Blue-PAS (Dimitroglou et al., 2010, Ferguson et al., 2010). The

157 intestinal perimeter ratios (arbitrary units, AU) were assessed after Dimitroglou et al. (2009) and the numbers of intraepithelial leucocytes (IELs) and goblet cells in the epithelium, across a standardized distance of $100 \mu \mathrm{m}$ (10 folds per specimen), was then calculated by averaging the cell numbers from all specimens (Ferguson et al., 2010). For scanning electron 
microscopy (SEM) and transmission electron microscopy (TEM), samples were washed in $1 \%$

162

163

164

S-carboxymethyl-L-cysteine for 30 seconds (SEM only) to remove mucus before fixing in $2.5 \%$ glutaraldehyde in sodium cacodylate buffer (0.1 M pH 7.2). samples were processed as described elsewhere (Dimitroglou et al., 2009) and screened with a JSM 6610 LV (Jeol, Tokyo, Japan) SEM or JEN 1400 (Jeol, Tokyo, Japan) TEM. The SEM images were analysed to assess microvilli count per $\mu \mathrm{m}^{2}$ (MCVT) and enterocyte apical area (EAA), $\mu \mathrm{m}^{2}$. The TEM images were analysed for microvilli length and diameter. All images were analysed with ImageJ version 1.47 (National Institute of Health, USA).

Enterocyte total absorptive surface (ETAS), $\mu \mathrm{m}^{2}$ was calculated according to the following:

$$
\operatorname{ETAS}=\left((2 \pi \times 1 / 2 \mathrm{MVD} \times \mathrm{MVL})+\left(\pi \times 1 / 2 \mathrm{MVD}^{2}\right)\right) \times \text { MVCT } \times \text { EAA }
$$

Where ETAS $=$ enterocyte total absorptive surface $\left(\mu \mathrm{m}^{2}\right) ; \pi=$ pie constant $=22 / 7 ;$ MVD $=$ microvilli diameter $(\mu \mathrm{m}) ; \mathrm{MVL}=$ microvilli length $(\mu \mathrm{m}) ; \mathrm{MVCT}=$ microvilli count $($ No. $\left./ \mu \mathrm{m}^{2}\right) ;$ and $\mathrm{EAA}=$ enterocyte apical area.

\subsection{Intestinal microbiology}

The GI tract was aseptically removed and faecal matter from the mid-intestine was isolated and processed on an individual fish basis. DNA was extracted from $100 \mathrm{mg}$ faecal matter after lysozyme (50 $\mathrm{mg} \mathrm{mL}^{-1}$ in TE buffer) incubation for $30 \mathrm{~min}$ at $37{ }^{\circ} \mathrm{C}$ using PowerFecal ${ }^{\circledR}$ DNA Isolation Kit according to the manufacturer's instructions.

\subsubsection{High-throughput sequencing analysis}

DNA extractions from the faecal matter were prepared for high-throughput sequencing as described by Standen et al. (2015). In brief, PCR amplification of the 16S rRNA V1-V2 region was conducted using primers $27 \mathrm{~F}$ (5' - AGA GTT TGA TCM TGG CTC AG-3' ) and 338R (5' -GCW GCC WCC CGT AGG WGT-3' ). Each PCR contain $0.5 \mu \mathrm{L}$ primer 

(Bioline), $22 \mu \mathrm{L}$ molecular grade water (Ambion) and $2 \mu \mathrm{L}$ DNA template. Thermal cycling was conducted using a TC-512 thermal cycler (Techne, Staffordshire, UK) under the following conditions: initial denaturation at $94{ }^{\circ} \mathrm{C}$ for 7 minutes, then 10 cycles at $94{ }^{\circ} \mathrm{C}$ for 30 seconds, touchdown of $1{ }^{\circ} \mathrm{C}$ per cycle from $62-53{ }^{\circ} \mathrm{C}$ for 30 seconds and $72{ }^{\circ} \mathrm{C}$ for 30 seconds. Furthermore, 20 cycles were performed at $94{ }^{\circ} \mathrm{C}$ for 30 seconds, $53{ }^{\circ} \mathrm{C}$ for 30 seconds and $72{ }^{\circ} \mathrm{C}$ for 30 seconds before a final extension for 7 minutes at $72{ }^{\circ} \mathrm{C}$. The quality of the PCR products was checked using agarose gel electrophoresis. PCR products were purified (QIAquick PCR Purification Kit; Qiagen) and quantified using a Qubit $^{\circledR} 2.0$ Fluorometer (Invitrogen). Before sequencing, the amplicons were assessed for fragment concentration using an Ion Library Quantitation Kit (Life Technologies TM, USA), the concentrations were then adjusted to $26 \mathrm{pM}$. Amplicons were attached to Ion Sphere Particles using Ion PGM Template OT2 400 kit (Life Technologies ${ }^{\mathrm{TM}}$, USA) according to the manufacturer's instructions. Multiplexed sequencing was conducted using Ion Xpress Barcode Adapters (Life Technologies ${ }^{\mathrm{TM}}$ ) and a $318^{\mathrm{TM}}$ chip (Life Technologies ${ }^{\mathrm{TM}}$ ) on an Ion Torrent Personal Genome Machine (Life Technologies ${ }^{\mathrm{TM}}$ ). The sequences were binned by sample and filtered within the PGM software to remove low quality reads. Data were exported as FastQ files.

Phylogenetic analyses were performed after the removal of reads with low quality scores $(\mathrm{Q}$ sorted by sequence similarity into a single fasta file, denoised and analysed using the QIIME 1.8.0 pipeline (Caporaso et al., 2010b). The USEARCH quality filter pipeline (Edgar, 2010) was used to filter out putative chimeras and noisy sequences and carry out OTU picking on the remaining sequences. The taxonomic affiliation of each OTU was determined based on the Greengenes database (DeSantis et al., 2006) using the RDP classifier (Wang et al., 2007) 
209 clustering the sequences at $95 \%$ similarity with a 0.80 confidence threshold and a minimum 210 sequence length of 150 base pairs. Non-chimeric OTUs were identified with a minimum

211 pairwise identity of $95 \%$, and representative sequences from the OTUs were aligned using 212 PyNAST (Caporaso et al., 2010a). To estimate bacterial diversity, the number of OTUs 213 present in the samples was determined and a rarefaction analysis was performed by plotting 214 the number of observed OTUs against the number of sequences. Good's coverage, Shannon215 Wiener (diversity) and Chao1 (richness) indices were calculated. The similarities between the 216 microbiota compositions of the intestinal samples were compared using weighted principal 217 coordinate analysis (PCoA) and unweighted pair group method with arithmetic mean 218 (UPGMA).

$219 \quad 2.7 \quad$ Statistical analysis

220 All data are presented as mean \pm standard deviation. Statistical analysis (except high221 throughput sequencing) was carried out using SPSS for Windows (SPSS Inc., 22.0, Chicago, 222 IL, USA). Data were checked for normality and equality of variance using Kolmogorov223 Smirnov and Bartlett's test, respectively. Where normal assumptions were met, data were 224 analysed using one-way analysis of variance (ANOVA) followed by a post-hoc Duncan test to determine significant differences. Where data violated these conditions after log transformation, a Kruskal- Wallis test was used. Differences between treatments were then determined using a Mann-Whitney U-test. For high-throughput sequence data, a KruskalWallis test was performed followed by pairwise comparison to compare alpha diversity metrics, and Vegan and ape packages of $\mathrm{R}$ were used to analyse the beta diversity of the groups. STAMP v2.1.3 and PRIMER V7 software (PRIMER-E Ltd., Ivybridge, UK) were used to distinguish differences at each taxonomic level for high-throughput sequence data. In

232 all cases significance was accepted at $P<0.05$. 


\subsection{Growth performance, feed utilisation and somatic indices}

235 Growth performance and feed utilisation was assessed using tilapia FBW, SGR, FCR and 236 PER (Table 2). Tilapia fed the diet supplemented with enz-pro performed better $(P<0.05)$ 237 than tilapia fed the control and probiotic supplemented diets in term of FBW, SGR, FCR and PER. However, there was no difference $(P>0.05)$ in the performance of tilapia fed the diet supplemented with the enzymes and those fed diet supplemented with enz-pro in terms of

240 FBW, SGR and FCR. The dietary treatment did not have a significant effect on the tilapia 241 somatic indices. A $100 \%$ survival was recorded in all the treatments.

\subsection{Haemato - immunological parameters}

243 The haemato-immunological parameters of tilapia fed the experimental diets are displayed in

244 Table 3 . Serum lysozyme activity was significantly higher $(P<0.05)$ in tilapia fed the 245 probiotic supplemented diet compared to serum lysozyme activity in tilapia fed the control 246 and enz-pro treatments. No differences were observed between treatments in any other 247 haematological parameter measured.

\section{$248 \quad 3.3 \quad$ Intestinal histology}

249 The mid-intestine of tilapia fed each of the experimental diets was examined by light 250 microscopy (Figure 1), scanning and transmission electron microscopy (Figure 2). Tilapia 251 from all treatments showed intact epithelial barriers with extensive mucosal folds extending 252 into the lumen. Each fold consisted of simple lamina propria with abundant IELs and goblet cells (Figure 1). Tilapia fed the diet supplemented with enz-pro had significantly higher perimeter ratio and microvilli count (density) compared to tilapia fed probiotic supplemented and control diets (Table 4). Goblet cells abundance was significantly higher $(P<0.05)$ in tilapia fed the diet supplemented with enz-pro than those fed the control diet. Microvilli 
257 diameter of tilapia fed a diet supplemented with enz-pro was larger $(P<0.05)$ than tilapia fed 258 the control diet. This translated to higher $(P<0.05)$ enterocyte absorptive area in tilapia fed 259 diets supplemented with enzymes and a combination of both enzymes and probiotic than 260 tilapia fed with the control diet.

\subsection{Intestinal microbiology}

262

A total of 536,602 sequence reads from the tilapia digesta were retained after trimming; after 263 removing low quality reads, $24,521 \pm 14,451,25,588 \pm 12,901, \quad 32,708 \pm 10,388$ and $24,503 \pm 12,255$ sequences for control, enzymes, probiotic and enz-pro treatments, respectively, were used for downstream analyses. Good's coverage rarefaction curves for the treatments reached a plateau close to 1 (0.9994 - 0.9996) (Figure 1a and Table 5), an indication that sufficient coverage was achieved and that the OTUs detected in the samples are representative of the sampled population.

269 The majority of reads derived from the tilapia digesta belonged to members of Fusobacteria (> 270 89\%) distantly followed by Proteobacteria (> 7\%) and Firmicutes (>0.4\%) (Figure 3c). Table 6 shows the most abundant genera in tilapia digesta. Cetobacterium, Aquaspirillum, Edwardsiella and Plesiomonas as well as unknown genera from the order Clostridiales,

273 family Clostridiaceae, class Gammaproteobacteria and order Aeromonadales were present in 274 all treatments with Cetobacterium being dominant (> 84\%) in all treatments. Cetobacterium accounted for $92.1 \%, 89.3 \%, 84.2 \%$ and $91 \%$ 16S rRNA reads in tilapia fed the control, enzymes, probiotic and enz-pro diets, respectively. Unknown genera from the families Leuconostocaceae and Methylocystaceae were present in the control, enzymes and probiotic 278 treatments but absent in the enz-pro treatment. Weissella and an unknown genus from the 279 family Methylocystaceae were present in the enzymes and probiotic treatments. Balneimonas was present in enzymes and enz-pro treatments. An unknown genus from the class 
Betaproteobacteria was also present in the control, probiotic and enz-pro treatments. probiotic treatment.

284 The alpha diversity parameters are presented in Table 5. There was no significant difference 285 between the treatments for the alpha diversity metrics assessed. Figure $3 b$ shows the beta diversity of the digesta through PCoA plots (based on Bray-Curtis dissimilarity matrix). The PCoA plot shows a spatial differentiation among the treatments.

\subsection{Discussion}

The previous reports on the use of exogenous digestive enzymes (Cao et al., 2007, Kumar et al., 2012, Castillo and Gatlin, 2015, Lemos and Tacon, 2016) and probiotic (Pandiyan et al., 2013, Pérez - Sánchez et al., 2014) as individual supplement in fish diet abounds. However, to the authors' knowledge no research has been conducted previously on the combined effects of exogenous digestive enzymes and probiotic on growth, intestinal morphology and microbiome of Nile tilapia. In this study, Nile tilapia were fed diet supplemented with enzymes, probiotic or a combination of both the enzymes and probiotic. Given the potential complimentary modes of actions of exogenous digestive enzymes and probiotic, the two products (when used in combination) could offer more benefits than when used alone. This is confirmed in this study with improved growth performance in terms of FBW, SGR, FCR and PER observed in tilapia fed diet supplemented with enz-pro a combination of enzymes and probiotic. The enhanced growth performance could be attributed to the ability of probiotic to produce fibre-degrading enzymes that may complement endogenous enzyme activity for digestion in fish (Roy et al., 2009, Ray et al., 2010, Ray et al., 2012) as well as the external exogenous enzyme capacity to increase the availability of suitable substrates for probiotic action (Bedford and Cowieson, 2012). In addition, the enzymes could positively affect the gut 
microbiota through improved digestibility and enhanced nutrient absorption and assimilation.

The indigestible NSPs and trypsin inhibitors that appear to induce necrotic enteritis in certain fish species are well known substrates for xylanase and protease enzymes respectively. Furthermore, xylanase may increase the digestion of NSPs (e.g. arabinoxylans) which could provide substrates for utilisation by gut bacteria (Bedford, 2000).

310 The use of enzymes and probiotic as individual supplements in this study did not have

311 significant effects on the growth performance of tilapia. This is somewhat contrary to the

312 results of Hlophe - Ginindza et al. (2015) who observed significantly improved growth

313 performance in tilapia (Oreochromis mossambicus) when an exogenous enzyme cocktail,

314 Natuzyme $^{\circledR}$ (containing protease, lipase, $\alpha$-amylase, cellulase, amyloglucosidase, $\beta$-glucanase,

315 pentosonase, hemicellulose, xylanase, pectinase, acid phosphatase and acid phytase) was

316 added to a plant-based diet. The inconsistency in the findings may be due to lower application

317 dosage of enzymes (75 mg kg-1 phytase, $300 \mathrm{mg} \mathrm{kg}^{-1}$ protease and $250 \mathrm{mg} \mathrm{kg}^{-1}$ xylanase)

318 used in the current study compared to $500 \mathrm{mg} \mathrm{kg}^{-1}$ used by Hlophe - Ginindza et al. (2015),

319 in addition to the broader diversity of enzymes in Natuzyme ${ }^{\circledR}$ or the different tilapia species.

320 On the other hand, the lack of effect on tilapia growth fed probiotic supplemented diet in the

321 current study is similar to the findings of $\mathrm{Ng}$ et al. (2014) who reported that dietary probiotic

322 (B. subtilis, B. licheniformis or Pediococcus sp.) had no effect on growth or feeding 323 efficiencies of tilapia. Shelby et al. (2006) also observed a non-effect of dietary Enterococcus

324 faecium and Pediococcus acidilactici or mixtures of B. subtilis and B. licheniformis on 325 growth of tilapia. However, B. subtilis when used solely as a dietary supplement was reported to be an effective growth promoter in tilapia (Aly et al., 2008), yellow croaker, Larimichthys crocea (Ai et al., 2011) and rohu, Labeo rohita (Nayak and Mukherjee, 2011). 
The improvement in intestinal morphology in the current study could be the result of complimentary changes to meet the increased rates of digestion and absorption after exposure to the diets. In this study, tilapia fed the diet supplemented with probiotic and enzymes presented a higher perimeter ratio, microvilli count (density) and larger diameter which translated to increased enterocyte absorptive area and subsequently resulted in the improved growth performance when compared with tilapia fed the control diet. This could be attributed to the combined effect of enzymes and probiotic to confer a superior beneficial effect than when used alone. However, there was no significant difference between intestinal histology of tilapia fed the control and probiotic supplemented diets. This is contrary to Standen et al. 337 (2015) who reported increased population of IELs, a higher absorptive surface area index and higher microvilli density in the intestine of tilapia fed a diet supplemented with AquaStar® Growout, a multi-species probiotic containing Lactobacillus reuteri, Bacillus subtilis, Enterococcus faecium and Pediococcus acidilactici. This difference could be attributed to different probiotic composition as well as application dosage which is $20 \mathrm{mg} \mathrm{kg}^{-1}$ in the 342 present study compared to $5 \mathrm{~g} \mathrm{~kg}^{-1}$ used by Standen et al. (2015).

343 In this study, the dietary treatment did not have significant effect on the tilapia 344 haematological parameters. Emadinia et al. (2014) also reported that supplementation of 345 poultry diets with an enzyme cocktail (xylanase, $\beta$-glucanase, cellulase, pectinase, phytase, 346 protease, lipase, and $\alpha$-amylase) had no effects on haemato-immunological parameters.

347 However, in the present study the serum lysozyme activity was significantly higher in tilapia 348 fed the probiotic supplemented diet compared to those fed the control and enz-pro 349 supplemented diets respectively. This is similar to the findings of Mandiki et al. (2011) who reported that dietary Bacillus probiotic have a stimulating effect on lysozyme activity in

351 Eurasian perch, Perca fluviatilis. Standen et al. (2013) also reported that dietary probiotic are able to stimulate innate immune response in tilapia. 
353 Gut microbiota may function to prevent pathogens from colonization of the intestinal tract.

354 The importance of commensal gut microbiota is highly important for normal functioning of

355 the immune apparatus of the GI tract in fish (Rawls et al., 2004, Pérez et al., 2010, Ringø et

356 al., 2015). The population size and composition of intestinal microbiota could influence the

357 extent of nutrient digestion and absorption by the host (Merrifield et al., 2010, Dimitroglou

358 et al., 2011, Bedford and Cowieson, 2012, Ray et al., 2012). In addition, GI microbiota are

359 understood to influence disease resistance, development, survival and feed utilisation (Denev

360 et al., 2009). Jiang et al. (2014) reported that dietary supplementation of xylanase affected the

361 abundance of Lactobacillus, Escherichia coli and Aeromonas in the intestine of juvenile Jian

362 carp. The intestinal microbiota of grass carp fed dietary cellulase changed in respect to

363 bacteria species and density (Zhou et al., 2013). Adeoye et al. (2016) also reported alteration

364 in the intestinal bacterial community profile of tilapia fed carbohydrase supplemented diet.

365 Similarly, several studies have reported the modulating effect of probiotic on fish GI

366 microbiota (Dimitroglou et al., 2011, Pandiyan et al., 2013, Pérez - Sánchez et al., 2014,

367 Standen et al., 2015). However, in the present study exogenous enzymes and probiotic did not

368 modify to a large extent microbial community of tilapia fed the experimental diets.

369 Regardless of the dietary treatments, certain OTUs such as Clostridiales, Cetobacterium,

370 Aquaspirillum, Gammaproteobacteria, Aeromonadales, Edwardsiella and Plesiomonas were

371 found in the intestinal tract of tilapia, forming core microbiome. This is similar to findings by

372 Larsen et al. (2014) who reported dominance of genus Cetobacterium in the gut of warm

373 water fish species. Similarly, shared core gut microbiota was observed in zebrafish

374 irrespective of geographical locations (Roeselers et al., 2011). Wong et al. (2013) also

375 reported core intestinal microbiota in rainbow trout being resistant to variation in diet and

376 rearing density. Similarly, the tilapia microbiome was quite stable and resistant to potential

377 changes in community abundance and diversity in response to the dietary supplements used 
378 in this study. However, the functionality of the microbiome may have been altered and this 379 may have contributed towards the improved performance of the tilapia fed the enzymes and 380 probiotic cocktail. Future studies should include metagenomics and metatranscriptomics of 381 the gut microbiome to investigate this hypothesis.

382 In conclusion, supplementation of tilapia diets with a combination of enzymes and probiotic 383 is capable of improving tilapia growth and intestinal histology without deleterious effect on 384 the fish health or intestinal microbiota. It is pertinent therefore to consider these finding for 385 the future development of diets specific for tilapia under a variety of culture conditions and 386 stages of growth from fry to fingerlings and on-growing to production (harvest) size. 
388 Acknowledgment

389 The authors are grateful to the Commonwealth Scholarship Commission in the UK and the 390 School of Biological Sciences, Plymouth University for funding. The authors also thank 391 DSM Nutritional Products and INVE Aquaculture for supplying the exogenous enzymes and 392 probiotic respectively. Members of staff at Faculty of Agriculture, King Mongkut's Institute 393 of Technology Ladkrabang, Thailand as well as peers in the Aquatic Animal Nutrition and 394 Health Research Group of Plymouth University are very much appreciated for technical 395 supports. 
ADEOYE, A., JARAMILlO-TORRES, A., FOX, S., MERRIFIELD, D. \& DAVIES, S. 2016. Supplementation of formulated diets for tilapia (Oreochromis niloticus) with selected exogenous enzymes: overall performance and effects on intestinal histology and microbiota. Animal Feed Science and Technology, 215,pp. 133-143.

AI, Q., XU, H., MAI, K., XU, W., WANG, J. \& ZHANG, W. 2011. Effects of dietary supplementation of Bacillus subtilis and fructooligosaccharide on growth performance, survival, non-specific immune response and disease resistance of juvenile large yellow croaker, Larimichthys crocea. Aquaculture, 317, 155-161.

ALY, S. M., ABD-EL-RAHMAN, A. M., JOHN, G. \& MOHAMED, M. F. 2008. Characterization of some bacteria isolated from Oreochromis niloticus and their potential use as probiotics. Aquaculture, 277, 1-6.

AOAC 1995. Official Methods of Analysis. Association of Official Analytical Chemists. Arlington, VA.

BATES, J. M., MITTGE, E., KUHLMAN, J., BADEN, K. N., CHEESMAN, S. E. \& GUILLEMIN, K. 2006. Distinct signals from the microbiota promote different aspects of zebrafish gut differentiation. Developmental biology, 297, 374-386.

BEDFORD, M. 2000. Removal of antibiotic growth promoters from poultry diets: implications and strategies to minimise subsequent problems. World's Poultry Science Journal, 56, 347-365.

BEDFORD, M. \& COWIESON, A. 2012. Exogenous enzymes and their effects on intestinal microbiology. Animal Feed Science and Technology, 173, 76-85.

CAO, L., WANG, W., YANG, C., YANG, Y., DIANA, J., YAKUPITIYAGE, A., LUO, Z. \& LI, D. 2007. Application of microbial phytase in fish feed. Enzyme and Microbial Technology, 40, 497-507.

CAPORASO, J. G., BITTINGER, K., BUSHMAN, F. D., DESANTIS, T. Z., ANDERSEN, G. L. \& KNIGHT, R. 2010a. PyNAST: a flexible tool for aligning sequences to a template alignment. Bioinformatics, 26, 266-267.

CAPORASO, J. G., KUCZYNSKI, J., STOMBAUGH, J., BITTINGER, K., BUSHMAN, F. D., COSTELLO, E. K., FIERER, N., PENA, A. G., GOODRICH, J. K. \& GORDON, J. I. $2010 \mathrm{~b}$. QIIME allows analysis of high-throughput community sequencing data. Nature methods, 7, 335-336.

CASTILLO, S. \& GATLIN, D. M. 2015. Dietary supplementation of exogenous carbohydrase enzymes in fish nutrition: a review. Aquaculture, 435, 286-292.

DENEV, S., STAYKOV, Y., MOUTAFCHIEVA, R. \& BEEV, G. 2009. Microbial ecology of the gastrointestinal tract of fish and the potential application of probiotics and prebiotics in finfish aquaculture. International aquatic research, 1, 1-29.

DESANTIS, T. Z., HUGENHOLTZ, P., LARSEN, N., ROJAS, M., BRODIE, E. L., KELLER, K., HUBER, T., DALEVI, D., HU, P. \& ANDERSEN, G. L. 2006. Greengenes, a chimerachecked 16S rRNA gene database and workbench compatible with ARB. Applied and environmental microbiology, 72, 5069-5072.

DIMITROGLOU, A., MERRIFIELD, D., MOATE, R., DAVIES, S., SPRING, P., SWEETMAN, J. \& BRADLEY, G. 2009. Dietary mannan oligosaccharide supplementation modulates intestinal microbial ecology and improves gut morphology of rainbow trout,(Walbaum). Journal of animal science, 87, 3226-3234.

DimitrogloU, A., MERRIFIELD, D. L., CARNEVAli, O., PICCHIETTI, S., AVELlA, M., DANIELS, C., GÜROY, D. \& DAVIES, S. J. 2011. Microbial manipulations to improve fish health and production-a Mediterranean perspective. Fish \& Shellfish Immunology, 30, 1-16.

DIMITROGLOU, A., MERRIFIELD, D. L., SPRING, P., SWEETMAN, J., MOATE, R. \& DAVIES, S. J. 2010. Effects of mannan oligosaccharide (MOS) supplementation on growth performance, feed utilisation, intestinal histology and gut microbiota of gilthead sea bream (Sparus aurata). Aquaculture, 300, 182-188.

EDGAR, R. C. 2010. Search and clustering orders of magnitude faster than BLAST. Bioinformatics, $26,2460-2461$. 
EMADINIA, A., TOGHYANI, M., GHEISARI, A., TABEIDIAN, S. A., ALE SAHEB FOSOUL, S. S. \& MOHAMMADREZAEI, M. 2014. Effect of wet feeding and enzyme supplementation on performance and immune responses of broiler chicks. Journal of Applied Animal Research, 42, 32-37.

FERGUSON, R., MERRIFIELD, D. L., HARPER, G. M., RAWLING, M. D., MUSTAFA, S., PICCHIETTI, S., BALCÀZAR, J. L. \& DAVIES, S. J. 2010. The effect of Pediococcus acidilactici on the gut microbiota and immune status of on - growing red tilapia (Oreochromis niloticus). Journal of Applied Microbiology, 109, 851-862.

GERAYLOU, Z., SOUFFREAU, C., RURANGWA, E., D'HONDT, S., CALLEWAERT, L., COURTIN, C. M., DELCOUR, J. A., BUYSE, J. \& OLLEVIER, F. 2012. Effects of arabinoxylan-oligosaccharides (AXOS) on juvenile Siberian sturgeon (Acipenser baerii) performance, immune responses and gastrointestinal microbial community. Fish \& shellfish immunology, 33, 718-724.

HLOPHE - GININDZA, S. N., MOYO, N. A., NGAMBI, J. W. \& NCUBE, I. 2015. The effect of exogenous enzyme supplementation on growth performance and digestive enzyme activities in Oreochromis mossambicus fed kikuyu - based diets. Aquaculture Research.

HU, J., RAN, C., HE, S., CAO, Y., YAO, B., YE, Y., ZHANG, X. \& ZHOU, Z. 2016. Dietary microbial phytase exerts mixed effects on the gut health of tilapia: a possible reason for the null effect on growth promotion. The British journal of nutrition, 1.

JIANG, T. T., FENG, L., LIU, Y., JIANG, W. D., JIANG, J., LI, S. H., TANG, L., KUANG, S. Y. \& ZHOU, X. Q. 2014. Effects of exogenous xylanase supplementation in plant protein enriched diets on growth performance, intestinal enzyme activities and microflora of juvenile Jian carp (Cyprinus carpio var. Jian). Aquaculture Nutrition, 20, 632-645.

KIRON, V. 2012. Fish immune system and its nutritional modulation for preventive health care. Animal Feed Science and Technology, 173, 111-133.

KUMAR, V., SINHA, A., MAKKAR, H., DE BOECK, G. \& BECKER, K. 2012. Phytate and phytase in fish nutrition. Journal of animal physiology and animal nutrition, 96, 335-364.

LARSEN, A., MOHAMMED, H. \& ARIAS, C. 2014. Characterization of the gut microbiota of three commercially valuable warmwater fish species. Journal of applied microbiology, 116, 13961404.

LEMOS, D. \& TACON, A. G. 2016. Use of phytases in fish and shrimp feeds: a review. Reviews in Aquaculture.

LI, H., ZHENG, Z., CONG-XIN, X., BO, H., CHAO-YUAN, W. \& GANG, H. 2010. Isolation of cellulose - producing microbes from the intestine of grass carp (Ctenopharyngodon idellus). Chinese Fishes. Springer.

LIU, H., GUO, X., GOONERATNE, R., LAI, R., ZENG, C., ZHAN, F. \& WANG, W. 2016. The gut microbiome and degradation enzyme activity of wild freshwater fishes influenced by their trophic levels. Scientific Reports, 6.

MANDIKI, S., MILLA, S., WANG, N., BLANCHARD, G., DJONKACK, T., TANASCAUX, S. \& KESTEMONT, P. 2011. Effects of probiotic bacteria on growth parameters and immune defence in Eurasian perch Perca fluviatilis L. larvae under intensive culture conditions. Aquaculture Research, 42, 693-703.

MERRIFIELD, D., BRADLEY, G., BAKER, R. \& DAVIES, S. 2010. Probiotic applications for rainbow trout (Oncorhynchus mykiss Walbaum) II. Effects on growth performance, feed utilization, intestinal microbiota and related health criteria postantibiotic treatment. Aquaculture nutrition, 16, 496-503.

MSANGI, S., KOBAYASHI, M., BATKA, M., VANNUCCINI, S., DEY, M. \& ANDERSON, J. 2013. Fish to 2030: Prospects for fisheries and aquaculture. World Bank Report.

NAKAGAWA, H., SATO, M. \& GATLIN III, D. M. 2007. Dietary supplements for the health and quality of cultured fish, Cabi.

NAYAK, S. K. 2010. Role of gastrointestinal microbiota in fish. Aquaculture Research, 41, 15531573. 
NAYAK, S. K. \& MUKHERJEE, S. C. 2011. Screening of gastrointestinal bacteria of Indian major carps for a candidate probiotic species for aquaculture practices. Aquaculture Research, 42, 1034-1041.

NG, W.-K., KIM, Y.-C., ROMANO, N., KOH, C.-B. \& YANG, S.-Y. 2014. Effects of Dietary Probiotics on the Growth and Feeding Efficiency of Red Hybrid Tilapia, Oreochromis sp., and Subsequent Resistance to Streptococcus agalactiae. Journal of Applied Aquaculture, 26, $22-31$.

OKUTANI, K., KAWADA, I. \& KIMATA, M. 1967. The chitinolytic enzyme present in the digestive tracts of yellow tail. Bull. Jap. Soc. Sc. Fish, 33, 848-852.

PANDIYAN, P., BALARAMAN, D., THIRUNAVUKKARASU, R., GEORGE, E. G. J., SUBARAMANIYAN, K., MANIKKAM, S. \& SADAYAPPAN, B. 2013. Probiotics in aquaculture. Drug Invention Today, 5, 55-59.

PÉREZ - SÁNCHEZ, T., RUIZ - ZARZUELA, I., BLAS, I. \& BALCÁZAR, J. L. 2014. Probiotics in aquaculture: a current assessment. Reviews in Aquaculture, 6, 133-146.

PÉREZ, T., BALCÁZAR, J., RUIZ-ZARZUELA, I., HALAIHEL, N., VENDRELL, D., DE BLAS, I. \& MÚZQUIZ, J. 2010. Host-microbiota interactions within the fish intestinal ecosystem. Mucosal immunology.

RAWLING, M. D., MERRIFIELD, D. L. \& DAVIES, S. J. 2009. Preliminary assessment of dietary supplementation of Sangrovit@ on red tilapia (Oreochromis niloticus) growth performance and health. Aquaculture, 294, 118-122.

RAWLS, J. F., SAMUEL, B. S. \& GORDON, J. I. 2004. Gnotobiotic zebrafish reveal evolutionarily conserved responses to the gut microbiota. Proceedings of the National Academy of Sciences of the United States of America, 101, 4596-4601.

RAY, A., GHOSH, K. \& RING $\emptyset$, E. 2012. Enzyme - producing bacteria isolated from fish gut: a review. Aquaculture Nutrition, 18, 465-492.

RAY, A. K., ROY, T., MONDAL, S. \& RINGØ, E. 2010. Identification of gut - associated amylase, cellulase and protease - producing bacteria in three species of Indian major carps. Aquaculture Research, 41, 1462-1469.

RINGØ, E., ZHOU, Z., VECINO, J., WADSWORTH, S., ROMERO, J., KROGDAHL, Å., OLSEN, R., DIMITROGLOU, A., FOEY, A. \& DAVIES, S. 2015. Effect of dietary components on the gut microbiota of aquatic animals. A never - ending story? Aquaculture Nutrition.

ROESElERS, G., MITTGE, E. K., STEPHENS, W. Z., PARICHY, D. M., CAVANAUGH, C. M., GUILLEMIN, K. \& RAWLS, J. F. 2011. Evidence for a core gut microbiota in the zebrafish. The ISME journal, 5, 1595-1608.

ROMERO, J., RINGØ, E. \& MERRIFIELD, D. L. 2014. The Gut Microbiota of Fish. Aquaculture Nutrition: Gut Health, Probiotics and Prebiotics, 75-100.

ROUND, J. L. \& MAZMANIAN, S. K. 2009. The gut microbiota shapes intestinal immune responses during health and disease. Nature Reviews Immunology, 9, 313-323.

ROY, T., MONDAL, S. \& RAY, A. K. 2009. Phytase - producing bacteria in the digestive tracts of some freshwater fish. Aquaculture research, 40, 344-353.

SAHA, S., ROY, R. N., SEN, S. K. \& RAY, A. K. 2006. Characterization of cellulase - producing bacteria from the digestive tract of tilapia, Oreochromis mossambica (Peters) and grass carp, Ctenopharyngodon idella (Valenciennes). Aquaculture Research, 37, 380-388.

SHELBY, R. A., LIM, C., YILDIRIM-AKSOY, M. \& DELANEY, M. A. 2006. Effects of probiotic diet supplements on disease resistance and immune response of young Nile tilapia, Oreochromis niloticus. Journal of Applied Aquaculture, 18, 23-34.

STANDEN, B., RAWLING, M., DAVIES, S., CASTEX, M., FOEY, A., GIOACCHINI, G., CARNEVALI, O. \& MERRIFIELD, D. 2013. Probiotic Pediococcus acidilactici modulates both localised intestinal-and peripheral-immunity in tilapia (Oreochromis niloticus). Fish \& shellfish immunology, 35, 1097-1104.

STANDEN, B., RODILES, A., PEGGS, D., DAVIES, S., SANTOS, G. \& MERRIFIELD, D. 2015. Modulation of the intestinal microbiota and morphology of tilapia, Oreochromis niloticus, following the application of a multi-species probiotic. Applied microbiology and biotechnology, 99, 8403-8417. 
WANG, Q., GARRITY, G. M., TIEDJE, J. M. \& COLE, J. R. 2007. Naive Bayesian classifier for rapid assignment of rRNA sequences into the new bacterial taxonomy. Applied and environmental microbiology, 73, 5261-5267.

WONG, S., WALDROP, T., SUMMERFELT, S., DAVIDSON, J., BARROWS, F., KENNEY, P. B., WELCH, T., WIENS, G. D., SNEKVIK, K. \& RAWLS, J. F. 2013. Aquacultured rainbow trout (Oncorhynchus mykiss) possess a large core intestinal microbiota that is resistant to variation in diet and rearing density. Applied and environmental microbiology, 79, 4974-4984. ZHOU, Y., YUAN, X., LIANG, X.-F., FANG, L., LI, J., GUO, X., BAI, X. \& HE, S. 2013. Enhancement of growth and intestinal flora in grass carp: the effect of exogenous cellulase. Aquaculture, 416, 1-7. 
568 Table 1. Dietary formulation and proximate composition $\left(\mathrm{g} \mathrm{kg}^{-1}\right)$ of experimental diets

\begin{tabular}{lrrrr}
\hline & Control & Enzymes & Probiotics & Enz-pro \\
\hline Commercial feed $^{\mathrm{a}}$ & 1000 & 999.94 & 999.98 & 998.92 \\
Phytase $^{\mathrm{b}}(\mathrm{mg})$ & 0 & 7.5 & 0 & 7.5 \\
Protease $^{\mathrm{c}}(\mathrm{mg})$ & 0 & 30 & 0 & 30 \\
Xylanase $^{\mathrm{d}}(\mathrm{mg})$ & 0 & 25 & 0 & 25 \\
Probiotics $^{\mathrm{e}}(\mathrm{mg})$ & 0 & 0 & 20 & 20 \\
Total & 1000 & 1000 & 1000 & 1000
\end{tabular}

Proximate composition (\% as fed basis)

$\begin{array}{lrrrr}\text { Moisture } & 8.03 \pm 0.04 & 6.87 \pm 0.14 & 8.06 \pm 0.06 & 6.63 \pm 0.09 \\ \text { Protein } & 34.32 \pm 0.28 & 34.78 \pm 0.09 & 34.43 \pm 0.13 & 34.56 \pm 0.08 \\ \text { Lipid } & 5.49 \pm 0.04 & 5.33 \pm 0.10 & 5.38 \pm 0.70 & 5.22 \pm 0.08 \\ \text { Ash } & 13.13 \pm 0.11 & 13.13 \pm 0.17 & 13.16 \pm 0.04 & 13.4 \pm 0.04 \\ \text { Energy }\left(\mathrm{MJ} \mathrm{kg}^{-1}\right) & 17.06 \pm 0.00 & 17.56 \pm 0.1 & 17.31 \pm 0.4 & 17.66 \pm 2.1 \\ \text { Fibre } & 3.65 \pm 0.06 & 3.15 \pm 0.12 & 3.15 \pm 0.07 & 3.21 \pm 0.05\end{array}$

$569{ }^{\mathrm{a}}$ No. 461, INTEQC Feed Co Ltd., Thailand

$570{ }^{\mathrm{b}} \mathrm{RONOZYME}{ }^{\circledR}$ Hiphos (contains 10,000FYT g ${ }^{-1}$ ) from DSM Nutritional Products

$571{ }^{\mathrm{c}} \mathrm{RONOZYME}{ }^{\circledR}$ ProAct (contains 75,000 PROT $\mathrm{g}^{-1}$ ) from DSM Nutritional Products

$572{ }^{\mathrm{d}} \mathrm{RONOZYME}{ }^{\circledR}$ WX (contains $1000 \mathrm{FXU} \mathrm{g}^{-1}$ ) from DSM Nutritional Products

$573{ }^{\mathrm{e}}$ Sanolife PRO-F (contains $1 \times 10^{10} \mathrm{CFU} \mathrm{g}^{-1}$ B. subtilis, B. licheniformis and B. pumilus) from

574 INVE Aquaculture 
576 Table 2. Growth performance, feed utilisation and somatic indices of tilapia fed the 577 experimental diets

\begin{tabular}{lllll}
\hline & Control & Enzymes & Probiotics & Enz-pro \\
\hline IBW $\left(\mathrm{g} \mathrm{fish}^{-1}\right)$ & $34.5 \pm 0.18$ & $34.54 \pm 0.05$ & $34.6 \pm 0.13$ & $34.61 \pm 0.29$ \\
FBW $\left(\mathrm{g} \mathrm{fish}^{-1}\right)$ & $138.04 \pm 2.44^{\mathrm{a}}$ & $139.49 \pm 2.83^{\mathrm{ab}}$ & $136.61 \pm 1.34^{\mathrm{a}}$ & $143.42 \pm 3.06^{\mathrm{b}}$ \\
SGR $\left(\%\right.$ day $\left.^{-1}\right)$ & $3.30 \pm 0.05^{\mathrm{a}}$ & $3.32 \pm 0.04^{\mathrm{ab}}$ & $3.27 \pm 0.02^{\mathrm{a}}$ & $3.38 \pm 0.04^{\mathrm{b}}$ \\
FI $\left(\mathrm{g} \mathrm{fish}^{-1}\right)$ & $92.24 \pm 0.92$ & $92.83 \pm 1.22$ & $92.35 \pm 0.27$ & $93.00 \pm 1.39$ \\
FCR & $0.94 \pm 0.02^{\mathrm{a}}$ & $0.93 \pm 0.02^{\mathrm{ab}}$ & $0.96 \pm 0.02^{\mathrm{a}}$ & $0.9 \pm 0.01^{\mathrm{b}}$ \\
PER & $2.49 \pm 0.06^{\mathrm{ab}}$ & $2.53 \pm 0.06^{\mathrm{b}}$ & $2.42 \pm 0.05^{\mathrm{a}}$ & $2.63 \pm 0.02^{\mathrm{c}}$ \\
HSI & $3.19 \pm 0.23$ & $3.18 \pm 0.26$ & $2.86 \pm 0.46$ & $3.10 \pm 0.02$ \\
VSI & $21.72 \pm 0.66$ & $21.44 \pm 2.96$ & $23.40 \pm 1.31$ & $21.83 \pm 1.61$ \\
K-factor & $2.11 \pm 0.08$ & $2.06 \pm 0.05$ & $2.10 \pm 0.07$ & $2.06 \pm 0.04$ \\
Survival $(\%)$ & 100 & 100 & 100 & 100
\end{tabular}

578 Means in the same row with different superscripts are significantly different $(P<0.05)$. IBW, 579 initial mean body weight; FI, daily feed intake; FBW, final mean body weight; SGR, specific 580 growth rate; FCR, feed conversion ratio; PER, protein efficient ratio; HSI, hepatosomatic 581 index and VSI, viscera-somatic index.

582

583

584

585 
586 Table 3. Haemato - immunological parameters of tilapia fed the experimental diets

\begin{tabular}{lllll}
\hline & Control & Enzymes & Probiotics & Enz-pro \\
\hline Haematocrit, $(\% \mathrm{PCV})$ & $40.11 \pm 3.34$ & $39.11 \pm 1.35$ & $41.67 \pm 3.48$ & $39.66 \pm 1.53$ \\
Haemoglobin, $\left(\mathrm{g} \mathrm{dL}^{-1}\right)$ & $11.35 \pm 1.21$ & $10.66 \pm 0.91$ & $11.93 \pm 2.50$ & $11.33 \pm 0.22$ \\
RBC $\left(10^{6} \mu \mathrm{L}^{-1}\right)$ & $1.74 \pm 0.10$ & $2.02 \pm 0.47$ & $1.92 \pm 0.32$ & $1.87 \pm 0.09$ \\
RBC $\left(10^{3} \mu \mathrm{L}^{-1}\right)$ & $20.28 \pm 1.34$ & $20.37 \pm 4.00$ & $20.59 \pm 0.08$ & $20.64 \pm 2.82$ \\
MCV (fL) & $232.53 \pm 12.95$ & $207.97 \pm 36.80$ & $223.30 \pm 34.69$ & $213.04 \pm 12.66$ \\
MCH $(\mathrm{pg})$ & $66.10 \pm 4.60$ & $56.25 \pm 6.66$ & $62.76 \pm 7.18$ & $61.00 \pm 4.19$ \\
MCHC $\left(\mathrm{g} \mathrm{dL}{ }^{-1}\right)$ & $28.29 \pm 1.59$ & $27.25 \pm 1.59$ & $28.75 \pm 3.98$ & $28.62 \pm 0.97$ \\
Lymphocytes $(\%)$ & $90.43 \pm 2.57$ & $91.40 \pm 2.38$ & $91.77 \pm 1.30$ & $89.43 \pm 3.54$ \\
Monocytes $(\%)$ & $5.14 \pm 1.87$ & $4.26 \pm 2.06$ & $3.94 \pm 0.54$ & $5.74 \pm 1.97$ \\
Granulocytes $(\%)$ & $4.42 \pm 0.70$ & $4.34 \pm 0.33$ & $4.29 \pm 0.76$ & $4.83 \pm 1.62$ \\
Serum lysozyme $(\mathrm{U})$ & $115.31 \pm 22.87^{\mathrm{a}}$ & $154.21 \pm 24.93^{\mathrm{ab}}$ & $170.39 \pm 22.98^{\mathrm{b}}$ & $127.97 \pm 6.43^{\mathrm{a}}$
\end{tabular}

587 Figures in each row with different superscript are significantly different $(P<0.05)$.

588 RBC, red blood cells; WBC, leucocytes; MCV, mean corpuscular volume (haematocrit $\left.589(\% \mathrm{PCV}) \times 10) / \mathrm{RBC} 106 \mu \mathrm{L}^{-1}\right) ; \mathrm{MCH}$, mean corpuscular haemoglobin (haemoglobin $\left(\mathrm{g} \mathrm{dL}^{-1}\right)$ $590 \mathrm{x} 10) / \mathrm{RBC}\left(106 \mu \mathrm{L}^{-1}\right)$; MCHC, mean corpuscular haemoglobin concentration (haemoglobin $\left.591\left(\mathrm{~g} \mathrm{dL}^{-1}\right) \times 100\right) /$ haematocrit (\%PCV); \%, mean percentage of total leucocytes; U, lysozyme 592 activity $\mathrm{mL}^{-1} \mathrm{~min}^{-1}$ 
594 Table 4. Intestinal histology of tilapia fed the experimental diets

\begin{tabular}{|c|c|c|c|c|}
\hline & Control & Enzymes & Probiotics & Enz-pro \\
\hline Perimeter ratio & $5.30 \pm 0.7^{\mathrm{a}}$ & $5.84 \pm 0.4^{\mathrm{ab}}$ & $5.22 \pm 0.5^{\mathrm{a}}$ & $6.72 \pm 0.8^{b}$ \\
\hline Goblet cells (per $100 \mu \mathrm{m})$ & $3.85 \pm 0.6^{\mathrm{a}}$ & $4.66 \pm 0.6^{\mathrm{ab}}$ & $4.55 \pm 0.6^{\mathrm{ab}}$ & $5.11 \pm 0.2^{b}$ \\
\hline IELs (per $100 \mu \mathrm{m})$ & $29.16 \pm 5$ & $29.48 \pm 2$ & $29.85 \pm 5$ & $28.68 \pm 4$ \\
\hline Microvilli count (per $\mu \mathrm{m}^{2}$ ) & $91.82 \pm 4^{\mathrm{a}}$ & $110.30 \pm 2.2^{b c}$ & $103.75 \pm 5.9^{b}$ & $115.17 \pm 6.5^{\mathrm{c}}$ \\
\hline Enterocyte apical area $\left(\mu \mathrm{m}^{2}\right)$ & $11.30 \pm 1.3$ & $12.39 \pm 1.4$ & $12.06 \pm 1$ & $12.47 \pm 2.1$ \\
\hline Microvilli length $(\mu \mathrm{m})$ & $1.24 \pm 0.04$ & $1.35 \pm 0.03$ & $1.32 \pm 0.2$ & $1.27 \pm 0.04$ \\
\hline Microvilli diameter $(\mu \mathrm{m})$ & $0.117 \pm 0.01^{\mathrm{a}}$ & $0.123 \pm 0.01^{\mathrm{ab}}$ & $0.123 \pm 0.01^{\mathrm{ab}}$ & $0.130^{\mathrm{b}}$ \\
\hline $\operatorname{ETAS}\left(\mu \mathrm{m}^{2}\right)$ & $499.9 \pm 82^{\mathrm{a}}$ & $762.17 \pm 85^{\mathrm{b}}$ & $674.55 \pm 145^{\mathrm{ab}}$ & $773.7 \pm 151^{\mathrm{b}}$ \\
\hline
\end{tabular}

595 Values with different superscripts indicate significant differences $(P<0.05)$. IELs, 596 Intraepithelial leucocytes; ETAS = enterocyte total absorptive surface $\left(\mu \mathrm{m}^{2}\right)$. 
599 Table 5. Number of reads, reads assigned to OTUs, Good's coverage and alpha diversity indices of allochthonous intestinal microbiota

600 composition between control, enzymes, probiotics and enz-pro treatments after 7 weeks of experimental feeding

\begin{tabular}{lllllll}
\hline & $\begin{array}{l}\text { Reads } \\
\text { (pre-trimming) }\end{array}$ & $\begin{array}{l}\text { Reads assigned } \\
\text { (post trimming) }\end{array}$ & Good's coverage & Observed species & $\begin{array}{l}\text { Shanon's diversity } \\
\text { index }\end{array}$ & Chao1 (Richness) Index \\
\hline Control & $41,748 \pm 22,108$ & $24,521 \pm 14,451$ & $0.9994 \pm 0.0001$ & $75.90 \pm 9.54$ & $2.82 \pm 0.10$ & $92.00 \pm 11.19$ \\
Enzymes & $42,898 \pm 20,096$ & $25,588 \pm 12,901$ & $0.9995 \pm 0.0007$ & $75.18 \pm 14.54$ & $2.78 \pm 0.14$ & $88.77 \pm 12.04$ \\
Probiotics & $57,638 \pm 15,492$ & $32,708 \pm 10,388$ & $0.9996 \pm 0.0002$ & $76.95 \pm 17.94$ & $3.20 \pm 0.60$ & $87.28 \pm 16.15$ \\
Enz-pro & $40,244 \pm 18,342$ & $24,503 \pm 12,255$ & $0.9994 \pm 0.0001$ & $72.12 \pm 7.10$ & $2.94 \pm 0.25$ & $88.04 \pm 8.18$ \\
\hline
\end{tabular}


604 Table 6. Abundance of the OTUs present in digesta samples (expressed as \%). General level 605 identification is presented where possible

\begin{tabular}{|c|c|c|c|c|}
\hline OTU & Control & Enzymes & Probiotics & Enz-Pro \\
\hline Cetobacterium & $92.1 \pm 3.8$ & $89.3 \pm 4.8$ & $84.21 \pm 4.3$ & $91.0 \pm 3.4$ \\
\hline Plesiomonas & $4.0 \pm 2.5$ & $7.7 \pm 4.4$ & $5.6 \pm 1.9$ & $4.0 \pm 2.2$ \\
\hline Unknown genus from order Aeromonadales & $2.4 \pm 2.4$ & $1.0 \pm 0.5$ & $3.1 \pm 2.4$ & $2.7 \pm 2.4$ \\
\hline Aquaspirillum & $0.9 \pm 0.4$ & $0.4 \pm 0.3$ & $1.2 \pm 1.3$ & $0.7 \pm 0.7$ \\
\hline Unknown genus from family Leuconostocaceae & $0.1 \pm 0.1$ & $0.2 \pm 0.3$ & $1.5 \pm 2.9$ & $0.0 \pm 0.0$ \\
\hline Unknown genus from family Leuconostocaceae & $0.1 \pm 0.2$ & $0.2 \pm 0.3$ & $2.0 \pm 3.9$ & $0.0 \pm 0.0$ \\
\hline Edwardsiella & $0.2 \pm 0.1$ & $0.6 \pm 0.7$ & $1.2 \pm 1.4$ & $0.3 \pm 0.1$ \\
\hline Unknown genus from order Clostridiales & $0.1 \pm 0.1$ & $0.2 \pm 0.1$ & $0.1 \pm 0.0$ & $0.1 \pm 0.1$ \\
\hline Unknown genus from family Clostridiaceae & $0.1 \pm 0.1$ & $0.1 \pm 0.1$ & $0.1 \pm 0.1$ & $0.1 \pm 0.1$ \\
\hline Unknown genus from class Gammaproteobacteria & $0.1 \pm 0.0$ & $0.1 \pm 0.1$ & $0.3 \pm 0.2$ & $0.1 \pm 0.1$ \\
\hline Unknown genus from class Betaproteobacteria & $0.2 \pm 0.3$ & $0.0 \pm 0.0$ & $0.6 \pm 1.2$ & $0.1 \pm 0.0$ \\
\hline Weissella & $0.0 \pm 0.0$ & $0.1 \pm 0.2$ & $0.7 \pm 1.4$ & $0.0 \pm 0.0$ \\
\hline Unknown genus from family Methylocystaceae & $0.1 \pm 0.1$ & $0.2 \pm 0.4$ & $0.3 \pm 0.6$ & $0.0 \pm 0.0$ \\
\hline Balneimonas & $0.0 \pm 0.0$ & $0.1 \pm 0.1$ & $0.0 \pm 0.0$ & $0.6 \pm 1.2$ \\
\hline Unknown genus from family Methylocystaceae & $0.0 \pm 0.0$ & $0.1 \pm 0.1$ & $0.2 \pm 0.3$ & $0.0 \pm 0.0$ \\
\hline Rhodobacter & $0.0 \pm 0.0$ & $0.0 \pm 0.0$ & $0.4 \pm 0.9$ & $0.0 \pm 0.0$ \\
\hline Leuconostoc & $0.0 \pm 0.0$ & $0.1 \pm 0.1$ & $0.1 \pm 0.2$ & $0.0 \pm 0.0$ \\
\hline Staphylococcus & $0.0 \pm 0.0$ & $0.0 \pm 0.0$ & $0.2 \pm 0.4$ & $0.0 \pm 0.0$ \\
\hline Corynebacterium & $0.0 \pm 0.0$ & $0.0 \pm 0.0$ & $0.1 \pm 0.2$ & $0.0 \pm 0.0$ \\
\hline Bacillus & $0.0 \pm 0.0$ & $0.0 \pm 0.0$ & $0.1 \pm 0.2$ & $0.0 \pm 0.0$ \\
\hline
\end{tabular}



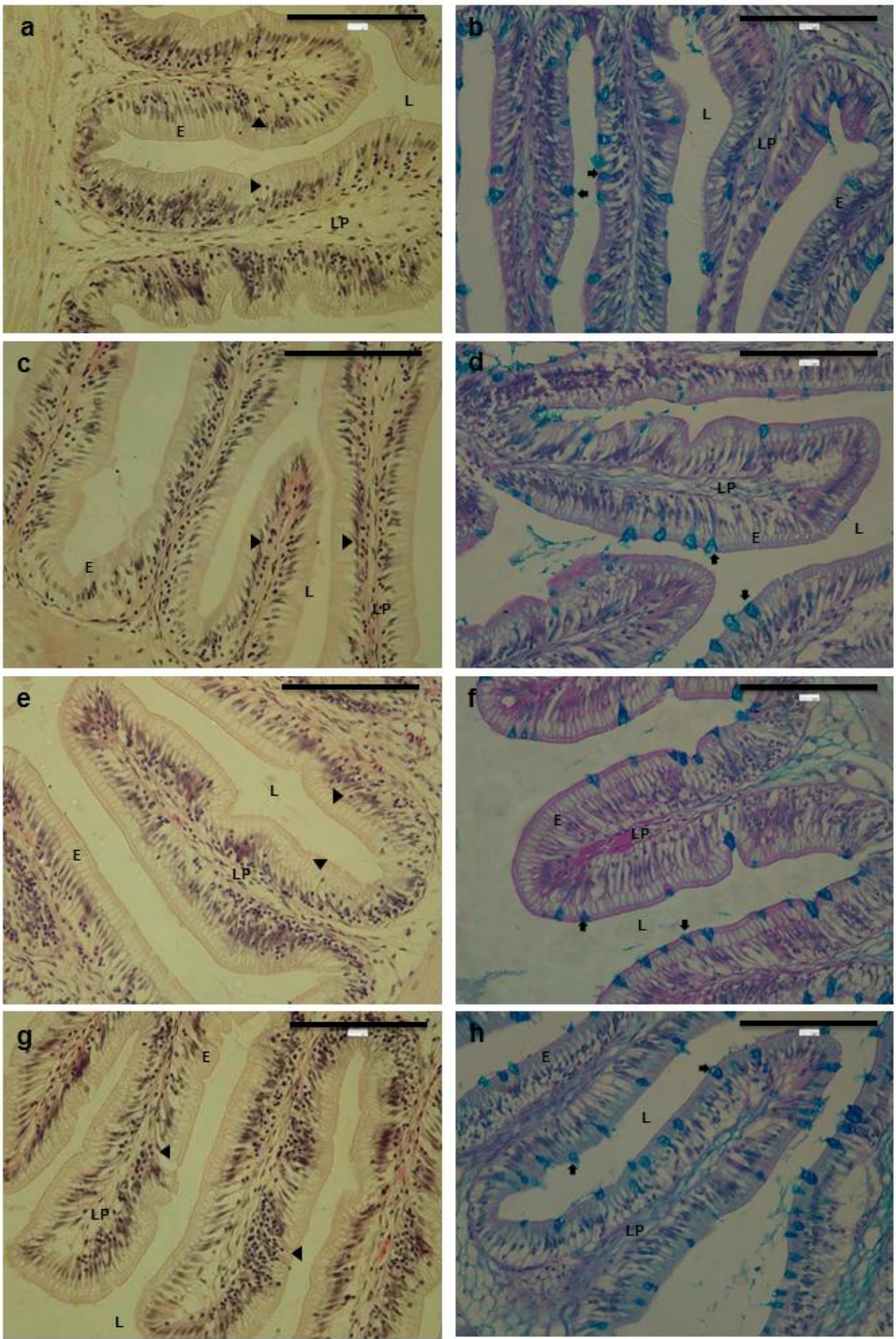

609 Figure 1. Light micrograph of the mid-intestine of tilapia fed control (a \& b), enzymes (c \&

$610 \mathrm{~d}$ ), probiotics (e \& f) and enz-pro ( $\mathrm{g} \& \mathrm{~h}$ ) diets. Goblet cells (arrows) and abundant IELs 611 (arrowheads) are present in the epithelia. Abbreviations are E enterocytes, LP lamina propria 612 and L lumen. Light microscopy staining: [a, c, e \& g] H \& E; [b, d, f \& h] Alcian Blue-PAS. 613 Scale bars $=100 \mu \mathrm{m}$. 


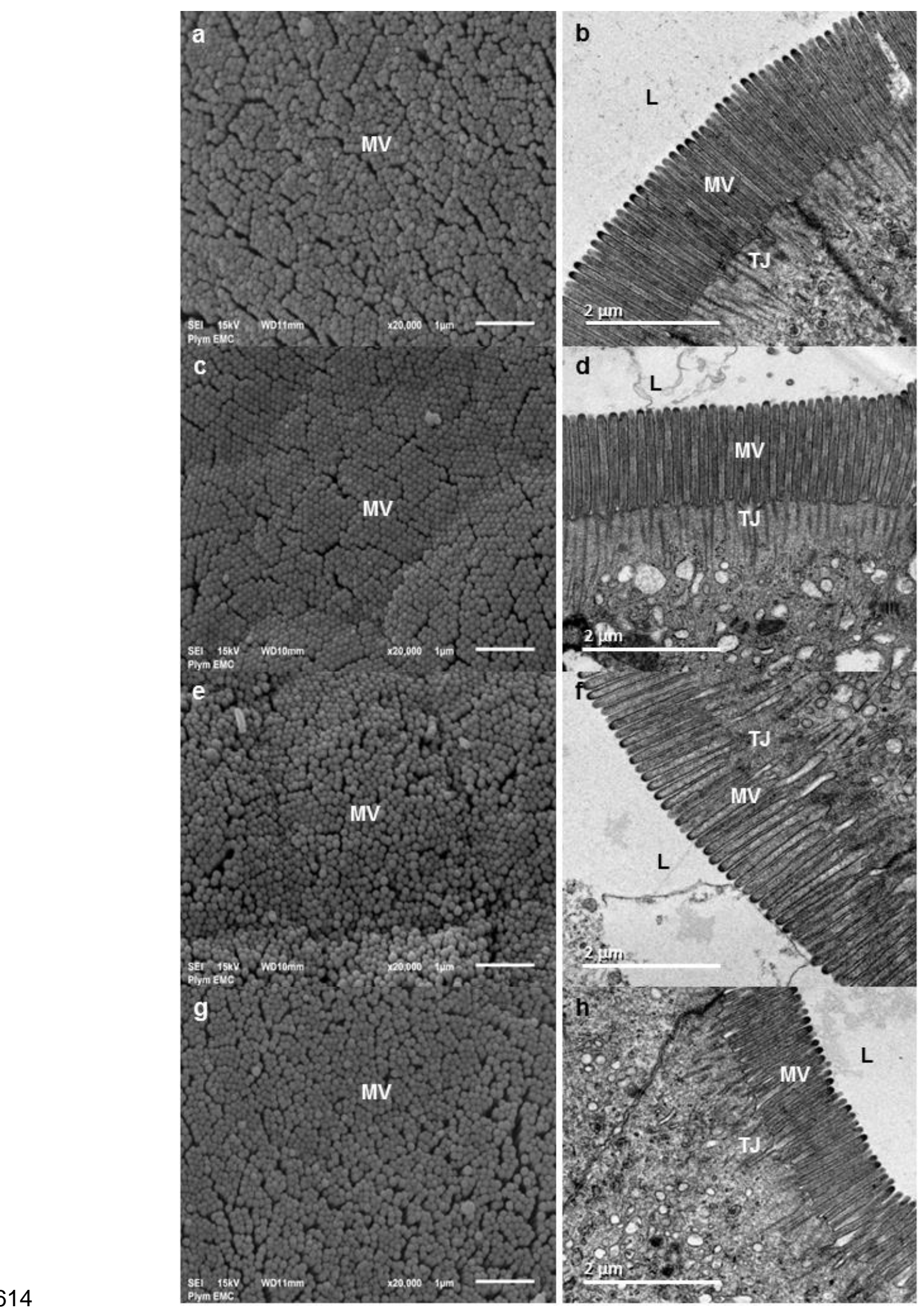

615 Figure 2. Scanning electron (a, c, e \& g) and transmission electron (b, d, f \& h) micrographs

616 of the mid-intestine of tilapia fed control ( $\&$ \& ), enzymes (c \& d), probiotics (e \& f) and 617 enz-pro $(\mathrm{g} \& \mathrm{~h})$ diets. Abbreviations are L lumen, TJ tight junction, MV microvilli. Scale 618 bars $=1 \mu \mathrm{m}(\mathrm{a}, \mathrm{c}, \mathrm{e} \& \mathrm{~g}), 2 \mu \mathrm{m}(\mathrm{b}, \mathrm{d}, \mathrm{f} \& \mathrm{~h})$. 


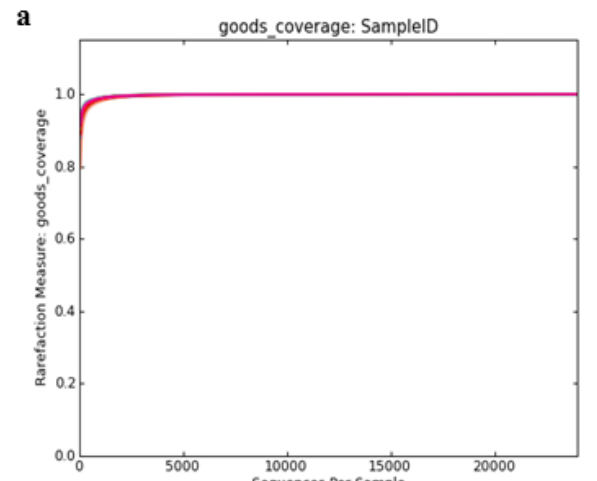

b

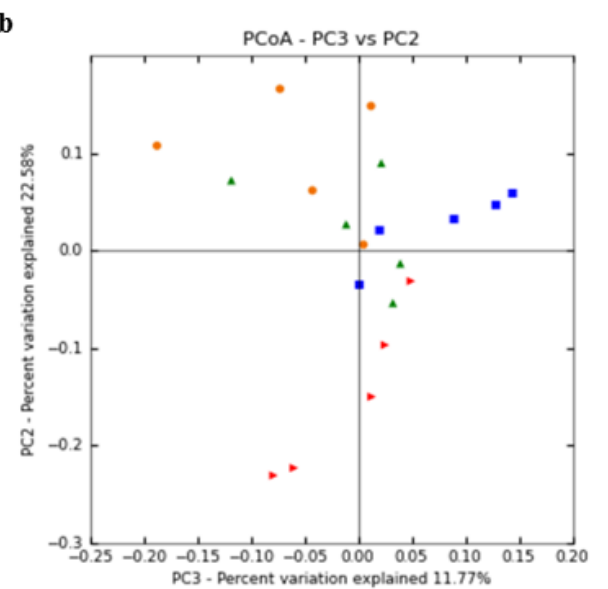

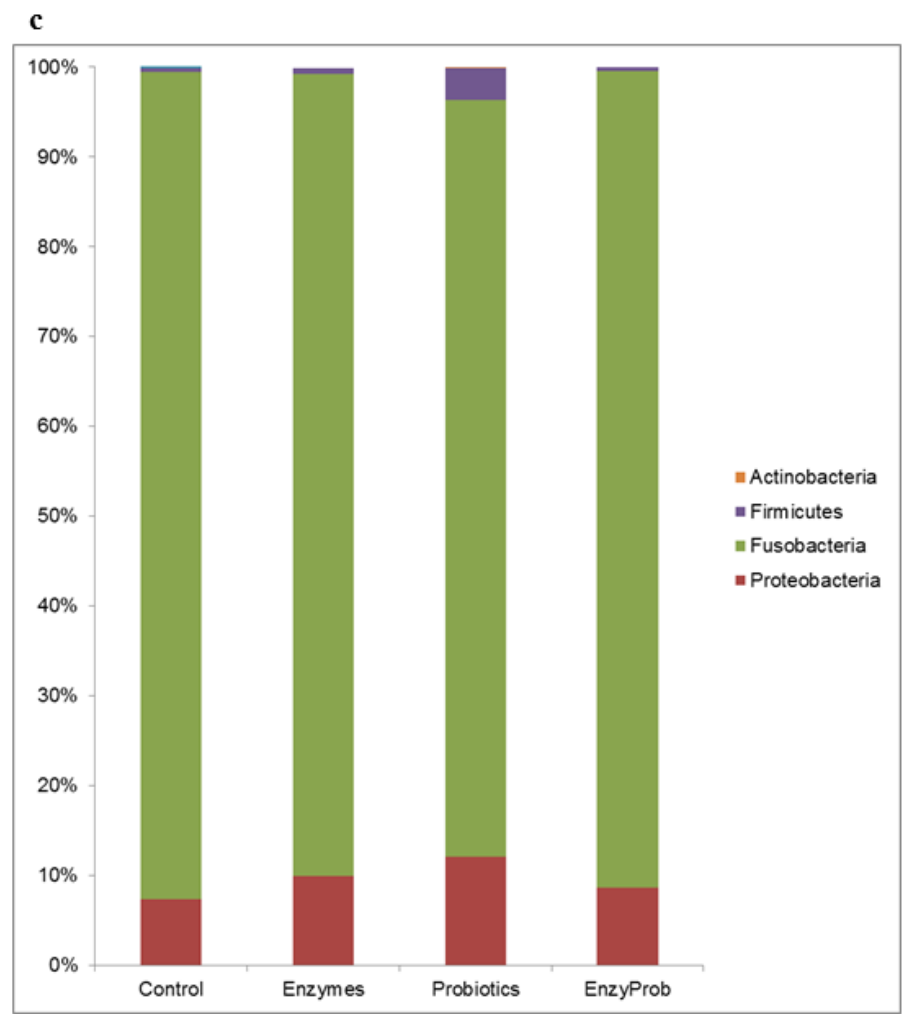

Figure 3. 16S rRNA V1-V2 high-throughput sequencing libraries of digesta from the tilapia intestine. (a) Good's coverage rarefaction curves of the tilapia digesta; (b) PCoA plots using Bray-Curtis dissimilarity matrix where data points represent samples from tilapia fed a control diet (red triangles), enzymes diet (blue squares), probiotic diet (green triangles) and enz-pro diet (orange circles); and (c) proportion of 16S rRNA reads from the tilapia digesta by dietary treatment assigned at the phylum level. 